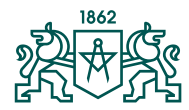

RIGA TECHNICAL UNIVERSITY
No. 5, Sept. 2021, pp. 107-129 https://doi.org/10.7250/HESIHE.2021.006

\title{
PROFESSIONAL AND SOCIAL ACTIVITIES OF ENGINEER JĀNIS JAGARS (1894-1970)
}

INDULIS ZVIRGZDIŅŠ*

Latvian Association for the History of Science

Summary. The research reveals facts about the family of engineer Jānis Jagars (1894-1970) and the versatility of his work in the 20th century. He studied at Riga Polytechnic Institute (RPI) and stayed in Russia during World War I. After returning to Latvia in the beginning of 1919, he graduated from the Baltic Technical University (BTU; Baltische Technische Hochschule, also Baltic Higher Technical School), which was established on the basis of RPI. J. Jagars participated in the activities of the Latvian Social Democratic Workers' Party (LSDWP), which supported his becoming the Head of the Riga City Construction Board. After the coup organized by Kärlis Ulmanis (1877-1942) he was arrested, then - released, after which he headed an engineering office. In June 1940, he joined the government headed by Augusts Kirhenšteins (1872-1963), where he held the position of Minister of Transport. He evacuated to the Soviet Russia during World War II. After the war, J. Jagars was an Assistant Professor at the State University of Latvia (SUL) and worked in various construction design institutes.

Keywords: Jānis Jagars, Riga Polytechnic Institute, Baltic Technical University, Riga City Construction Board, State University of Latvia.

\section{An Insight into the Jagars Family}

During the research, the author studied the autobiography written by engineer J. Jagars around 1968 for the period up to 1940 [1], the personnel files of his employees in the archives of the SUL and the Institute of Architecture and Construction of the Latvian SSR Academy of Sciences, the Latvian Museum of Architecture as well as the press materials in Latvian libraries, which contain extensive and comprehensive information about the life and work of J. Jagars as well as the Jagars family.

* Corresponding author.

E-mail: zviindulis6@inbox.lv

(C) 2021 Indulis Zvirgzdiņš. Publisher RTU Press.

This is an open access article licensed under the Creative Commons Attribution License

(http://creativecommons.org/licenses/by/4.0/). 
The aim of the research is to analyse the sources and literature in order to evaluate the professional and social activities of J. Jagars and the role of the family in his life.

The Jagars Family (in the records of Ergli Manor (1826-1858) the surname was spelled as Gegors) were tenants of about 90 hectares of land at «Kalna Ramulēni» in Ërgli Parish, because the owner of Érgli Manor Eduard Friedrich Alwil Rembert Rudolf von Transehe-Roseneck (1858-1928) began selling farmsteads to farmers only shortly before World War I.

On the day of Summer Solstice 1887, Andrejs the son of Andrejs Jagars (1858-1942) married Anna Kiesnere (?-?) from the nearby house «Kranci» [2]. They had three children: Marija (1888-1980; married name Bērzina), Andrejs (1892-1969), and Jānis (1894-1970). The father of three children, A. Jagars, attended a county school in Riga and after graduating from it was planning to study, but he had to return to Ergli and take over the land management from his father Andrejs Jagars (18121901) [1; p. 1]. He took part in the local cultural life, was also elected Chairman of the Parish Court. During the performance of these duties, he had disagreements with E. R. von Transehe-Roseneck, therefore in 1902 the family moved from Ergli to Riga and settled in the vicinity of Šmerlis. The fact that Andrejs Jagars wanted to provide his children with better educational opportunities also partially facilitated his departure from Ergli. When his sister Marija taught her older brother Andrejs to read, Jannis also learned to read at the age of five and when he was seven, he started studying at the Ërgli Lutheran Congregational School, which was also attended by his brother Andrejs. In Riga, both brothers entered the Tsar Peter I Vocational School, Andrejs was admitted to the first grade but Jannis - to the preparatory class. Andrejs studied in the building near the Second Riga City Theatre from 1903 to 1911, completed the full course and an additional class [3]. Already during his studies he earned his living as a private teacher, he successfully completed his own studies - he was the most successful student in the class.

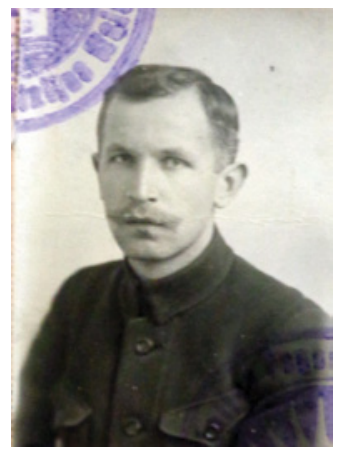

Figure 1. Jānis Jagars in 1919. 
After graduating from the Vocational School, his brother Jānis went to study at Petersburg (now - Saint Petersburg) Electrotechnical Institute. In his memoirs Andrejs wrote: «My brother graduated from secondary school a year before me and went to study in Petersburg, where he had to pass a tough competition to enter the Electrotechnical Institute there were 10 times more examinees than vacancies. I have to say that my brother did not learn as easily as I did. This made him work more systematically and focus on narrower issues. And, in the end, he knows his field of activity - electrotechnics - so well that I have to admit that I do not have such a deep and thorough knowledge in any field» $[1 ;$ p. 6].

During World War I, in the autumn of 1915, Jānis' parents moved to Petrograd (St. Petersburg from 1914 to 1924) to their eldest son Andrejs, where daughter Marija and her husband also lived. After World War II, the families of J. Jagars and his sister Marija lived in Latvia, whereas their parents and their brother Andrejs went into exile and in 1950 arrived in the United States. In the last years of his working life, father Andrejs Jagars took the position of Chief Electrical Engineer at the Capitol in Washington, USA [4]. His son Andrejs Jagars (1927-1984) also lived there.

Figure 2. Jānis, Marta, Rūta and Jānis Jagars (c. 1940).

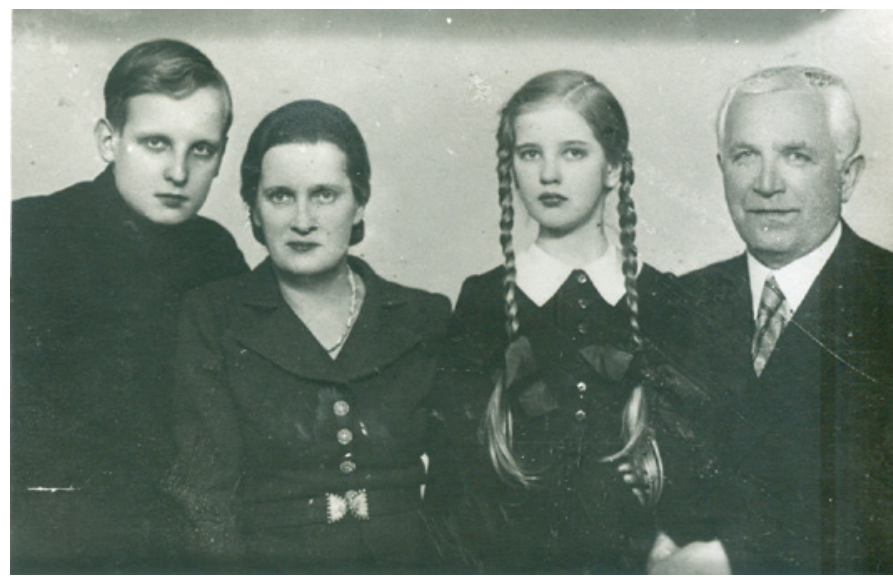

In November 1925, Jānis Jagars married Marta Dēkena (1894-1945), a graduate (1925) of the Faculty of Economics and Law of the University of Latvia, whose father, teacher Kärlis Dékens (1866-1942), was the Chairman of the Riga City Council, a member of the People's Council, the Deputy of the Constitutional Assembly and of the first four Saeima from LSDWP. Marta's sister Anna Dēkena (1892-1979) was married to poet Valdis Grēvinšs (1895-1968). The Jagars Family had a son Jānis (1927-1980) and a daughter Rūta (1931-1996; road engineer). The Jagars Family and their housekeeper Anna Medne (?-?) lived at 7 Pulkveža Brieža Street, apartment No. 2, and from May 1926 - in a five-room 
apartment with a kitchen and a maids' room at 67 Krišjānna Valdemāra Street, apartment No. 19 [5]. The house on K. Valdemära Street belonged to the community of tenants. The closest neighbours in the apartment No. 18 were the family of General Andrejs Auzāns (1871-1953), while in apartment No. 6, in the autumn of 1926 settled politician and public figure Klāvs Lorencs (1885-1971) with whom J. Jagars collaborated mostly as members of the Social Democratic Party. J. Jagars' family also had a summer house in Ogre, at 10 Kalna Avenue.

\section{Study Years of Jānis Jagars}

J. Jagars was aware that if he were going to study in Petersburg or Moscow, his parents would not be able to support him, therefore on 1 September 1911, he entered Riga Polytechnic Institute. He considered whether to study in the Department of Architecture, Engineering or Machine Engineering, but chose the latter, although he thought it would be the most difficult to study. During his studies, J. Jagars also took part in social life, participated in the Mechanics Club and student society «Stars» [6]. The Society was left-leaning and was partly the opposite of corporations.

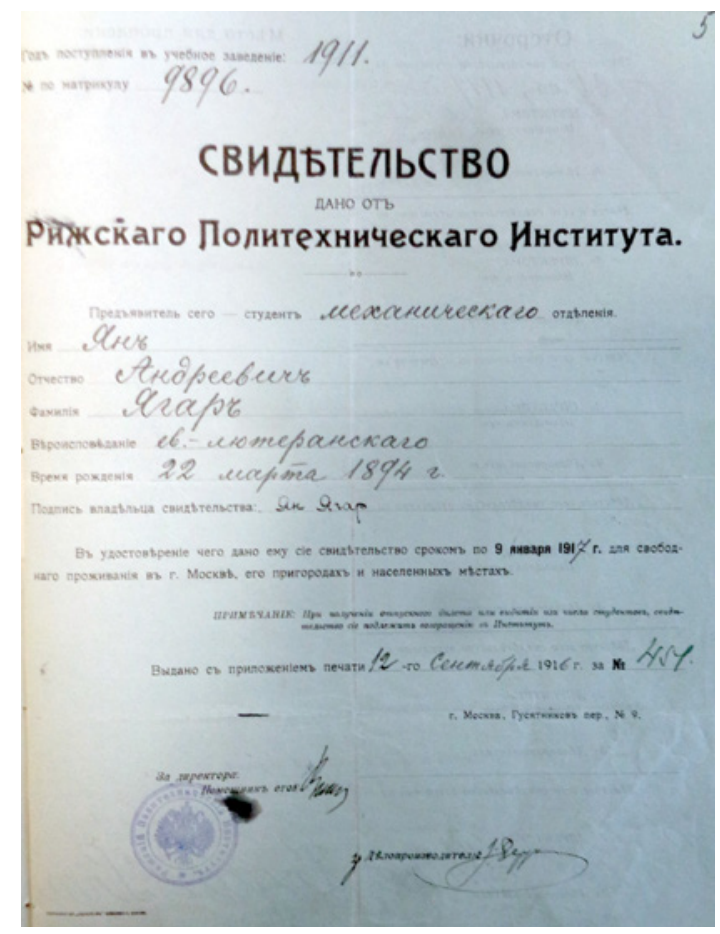

Figure 3. Certificate of J. Jagars studies at RPI (1916). 
As a student, J. Jagars continued to work as a private teacher, and during World War I, he also got took other paid jobs. In the summer of 1915 he was an assistant driver of a locomotive on the Riga-Orel railway line. In December, Jānis Jagars became a draftsman for three months at the Mechanical Engineering Factory of Yakov Aivaz (Яков Моисеевич Айваз; 1861-1930) in Petrograd. Riga Polytechnic Institute was in an evacuation in Moscow at that time. J. Jagars continued his studies with interruptions. In the summer of 1916, he worked in Rostov (now - Rostov-on-Don) in the design office of the Agricultural Tool Factory «Aksay» («Аксай»; this factory also produced some of the first cars in Russia). In October 1917, he resumed his studies at the Institute in Moscow as a free listener, and in April 1918, became a full-fledged student again [7]. In Moscow, J. Jagars experienced the Russian Revolution of February 1917 and was among the most active students of that time. In his memoirs he described this period as follows: «After the February Revolution, corporations were very active in Riga Polytechnic Institute, based on their strict discipline, to mobilize all their members to try to subordinate the vast masses of unorganized students to student leadership in general meetings, which would then be used to fight the revolution. However, it turned out that most of the unorganized students are more sympathetic to «Stars» calls for everyone to fight for the defence of the conquests of the revolution and their further development. (..) In this mood, our list won a large majority of voices in the student council elections, where two lists were submitted for voting - one drawn up by corporations and the other created by «Stars» (with me as the first candidate)» [1; p. 8]. J. Jagars was elected the Chairman of the RPI Student Council. He also headed the Student Socialist Office. He attributes his membership of the Latvian Social Democratic Workers' Party to the time a year later. Researchers of the history of the restored Riga Polytechnic Institute in the 1960s found a document of the spring of 1917 in which Jagars was mentioned, but they neither looked for nor questioned him, although they knew that Jagars was living in Riga after the war [8].

In Moscow, the would-be engineer began collecting materials for a diploma thesis, the supervisor of which was Nikolai Schiemann (1865-1944), a graduate of Riga Polytechnicum (RP; 1893) and AdjunctProfessor. Again, there was a lack of funds, and with the help of the studio and «Stars» partner Edgars Krievs (1892-1978) he managed to find a job in the design office of a cement factory in the port city of Kunda in northern Estonia. He was elected a Member of the Council of Factory Servants, according to J. Jagars, the Council concluded the first collective agreement between employees (servants) and the administration in Estonia. He also participated in the activities of the Council of Rakvere 
Workers' and Soldiers' Deputies. His leftist views were the cause of threats after the German occupation in the beginning of 1918, therefore J. Jagars took the opportunity to return to Riga in June, resumed the preparation of his diploma thesis under the supervision of N. Schiemann and did not miss social activities.

On 24 November 1918 [9] (mentioned elsewhere 23 November [10]) Jänis Jagars chaired the meeting of students of the BTU in the premises of $V$. Olavs Commercial School, at 26 Marijas Street. A few days after the proclamation of the Republic of Latvia, the students prepared a congratulation paper to the People's Council and the Provisional Government. In it was pointed out that students who had been in Russia experienced how one party seized the power by dagger. The issue of the language of instruction at the university was discussed. The state of Latvia was established, so the transition to studies in Latvian was expected, and it was necessary to oppose German as the language of instruction at the university, Russian was still allowed. On behalf of the meeting, a letter was prepared on 25 November to the Minister of Public Lighting (Education) Kärlis Kasparsons (1865-1962) which was signed by Jānis Jagars and two former RPI students - Jānis Asars (1895-1978) and Voldemārs Mežvēvers (1888-1984). The letter asked that the university is taken back into the subordination of the Ministry in order to facilitate the return of the Latvian scientists to their homeland and the training of teaching staff from local students, and the admission of secondary school graduates to the university without obstacles. J. Jagars did not support the call of the members of the student corporations «Selonija» and «Tālavija» for students to join the Security Service of the Provisional Government [11].

In the beginning of 1919, J. Jagars and four other fellow students defended their diploma theses at the BTU (established on the basis of RPI after the re-evacuation of RPI from Russia). BTU operated from 1 October 1918 to 3 January 1919. J. Jagars received a temporary certificate for having completed a full course at the Department of Mechanics of RPI and in accordance with the decision of the examination commission was awarded the qualification of an engineer-technologist. Within six months, this certificate had to be reissued into a university diploma [12; p. 5.]. Apparently, this did not happen. When J. Jagars wanted to register with the Construction Department of the Ministry of the Interior to obtain construction rights in the middle of the 1920s, the conclusion about his education was as follows: «During the Soviet era, he graduated from a foreign university in the territory of Latvia in the program of Riga Polytechnic Institute». A reference from the University of Latvia was requested and at the sitting of the Cabinet of Ministers of 28 September 1925 a decision was taken to grant «the professional 
rights of an engineer-technologist to Jānis Jagars who graduated from the Baltic Technical University» [13]. At the time, this was the case for determining the rights of foreign graduates, for example, at the next meeting of the Cabinet of Ministers on 2 October, Fricis Menders (18851971), J. Jagars' party member, graduate of the Faculty of Law of the University of Bern was granted professional rights of law graduates of university education institutions [14].

\section{Latvian War of Independence}

The work of engineer J. Jagars in the acquired profession lasted only a few months. The War of Independence began, and in the autumn of 1919, engineer J. Jagars also took part in it. In October, he together with several students joined the Student Battalion to take part in the defence of Riga against the Bermontians attack. He was in the unit commander of which was lawyer Jānis Ducens (1888-1925). At the beginning, the unit was located in the Schmidt Oil Factory in Tornakalns, then, anticipating a rapid approach of the opponent after the break of the front, retreated across the bridge to the right bank of the Daugava and fortified between the railway and the Luebeck bridge. At night, J. Jagars was sent across the river for reconnaissance, the opponent was not met and he returned happily, soon after the middle part of the bridge was lifted. Regular army units arrived and diverted the student unit to guard the buildings [1; pp. 10-11]. There, J. Jagars was met by the Minister of Agriculture Augusts Kalniňš (1876-1940), with whom they had previously met at the «Stars» society. On his initiative, the engineers appointed him as the Head of the Workshops of the Latvian Army Aviation Park for a couple of months [15]. Eleven years later, in November 1930, J. Jagars, a volunteer of the Student Battalion and a member of the Riga City Board, was awarded the Order of the Three Stars of the 4th Class [16]. On this day 18 students of the Student Battalion were awarded the 5th Class Order.

\section{Jānis Jagars - Engineer and Politician. 1919-1934}

Immediately after graduating from the university, Jānis Jagars was recruited by the Committee on Agriculture as Peat Officer, on the recommendation of Ādolfs Kiršteins (1884-1926), his fellow member in the society «Stars». His direct supervisor was Pēteris Nomals (18761949), a graduate (1910) of the Department of Chemistry of RPI and the founder of peatland research in Latvia. The engineer continued to work in the field also when serving in the Ministry of Agriculture of the 
Republic of Latvia, from July 1919, when the Provisional Government returned to Riga. As the structural units of the Ministry changed, the title of the position also changed over time [17]. Initially, the Department of Land Reclamation had a Peat Division, later it was renamed the Peatland Research Division, then - the Peat Utilization Board, headed by Jannis Jagars. At the time, his brother Andrejs Jagars also worked in the Ministry of Agriculture, who until the spring of 1923 was the Head of the Technical Unit of the Department of Agriculture and focused on mechanization of work.

For a short time in the first half of July 1919, J. Jagars also participated in the Social Democratic faction of the People's Council, until not all the permanent members of the faction had managed to return to Riga. In the afternoon of 13 July, the People's Council held the third session. The formation of a new Cabinet of Ministers was discussed, as the previous government had submitted a resignation letter. The Farmers' Union nominated K. Ulmanis the Prime Minister. He was elected with the Social Democrats abstaining [18].

In his work as engineer J. Jagars had to deal with areas that he had not been interested in before, so he had to learn a lot. His business trips to Belgium, Denmark, the Netherlands, Norway, Finland and Sweden also helped him to get acquainted with the extraction and utilization of peat. At that time, peat was used mainly as fuel, but in Latvia it made a small part of the total balance. The role of peat was also reduced by the import of cheap Silesian coal. In February 1922, it was decided to start the liquidation of the Peat Utilization Board, and from 1 August, it was merged with the Technical Unit of the Department of Forests, headed by senior engineer J. Jagars [19]. The Unit planned to expand the areas of supervision in the future. In December 1922, the engineer together with lawyer Voldemārs Zāmuels (1872-1948) was sent on a trip to Norway - it was necessary to settle the issue of the Ministry of Agriculture's contract for the purchase of forestry equipment a few years ago, which Latvia later refused to sign due to inadequate equipment. As compensation for the breach of contract the manufacturer requested the right to use a certain amount of Latvian timber. The activities of the Department of Forests were criticized at the end of the year, the former Minister of Agriculture, a graduate (1908) of the Department of Chemistry of RPI Augusts Kalniňs (1876-1940) and the head of the Technical Unit J. Jagars [20] were criticised as well. In 1922, engineer J. Jagars also was invited to manage the Department of Labour of the Riga City Board, which administered the registration of the unemployed, organized social work for them, supervised the Birth Registry Office, registered rookies, etc., but he rejected the offer. 
In August 1921, a Conference of Latvian Engineers and Technicians (engineers - with higher education, technicians - with secondary special) took place, where it was decided to establish a joint organization, the so-called Office of the Latvian Congress of Engineers and Technicians. Until then, there were smaller specialized societies (architecture, electricity, chemistry, surveying and cultural engineering) as well as associations based on the nationality principle. J. Jagars participated in the development of the statutes of the Office, served on the Board of the Office, he also headed the Latvian Union of Engineers. In 1924, the Jagars brothers took part in tours to Poland and Finland organized by the Society of Engineers, and visited several industrial companies. One of the suggestions made by the Office was that graduates of Russian and other foreign universities should have the same rights as the graduates of the UL [21]. It was also in J. Jagars' interests.

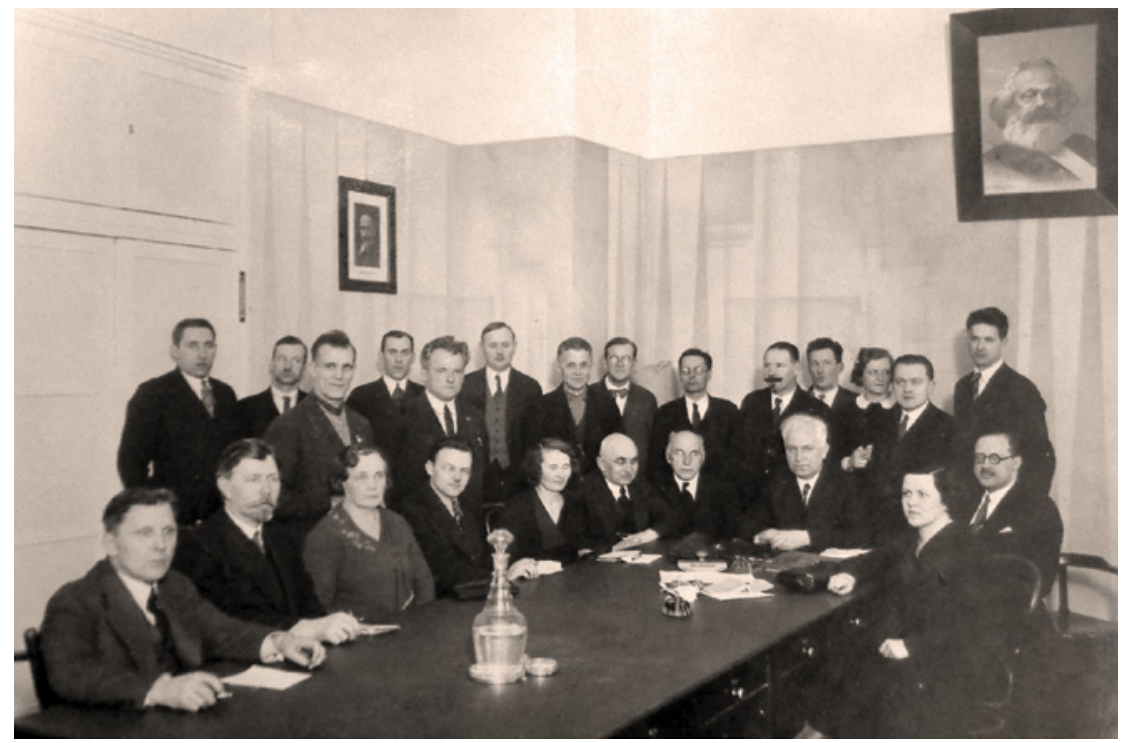

Figure 4. LSDWP Riga City Committee (early 1930s). J. Jagars - at the end of the table.

On 23 February 1923, J. Jagars started working as the Head of the Riga City Construction Board. Not only education and work experience but also party affiliation were of importance in the new position. LSDWP deputies in the Riga City Council were a significant force - about a third, they nominated heads of several departments of the board at different times. Before J. Jagars, the head of the Construction Board had been changed every year. The following persons had held this position before: Paul Riebensahm (1861-1947), a graduate (1885) of the Department 


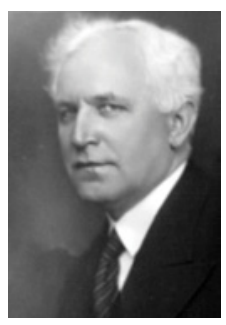

Figure 5. J. Jagars (c. 1934). of Engineering of RPI; Peter Ladigin (Петр Ладыгин Васильевич; 1879-1942), a graduate (1904) of the Department of Architecture of RPI; Augusts Šteins (1881-1957), a graduate of the Department of Mathematics of the University of Kazan; and Georgs Ulmans (18761947), a graduate (1901) of the Department of Machine Engineering of RPI. J. Jagars held the position until May 1934. At that time, the City Board consisted of the Mayor with his members (deputies) and heads of nine departments (the Construction Board - one of them). The Construction Board was in charge of the construction, reconstruction and maintenance of city buildings (schools, hospitals, markets, administration and institutional buildings, detached houses, etc.), street, road and bridge management, water supply and sewerage, and the fire service [22]. It reviewed, evaluated and approved all constructionrelated projects in the city. The construction of the city's facilities was mainly carried out by private companies, but auctions for the supply of works and materials had to be prepared and organized. The Construction Board's announcements about the auctions were mainly published in two publications - newspaper «Sociāldemokrāts» and journal «Latvijas Inženieru un Tehniķu Kongresa Biroja Žurnāls» (Journal of the Office of the Latvian Congress of Engineers and Technicians) - it was most likely the choice of the Head of the Construction Board which publications could earn from advertising. J. Jagars also ran for the City Council elections in 1925, 1928 and 1931 from the LSDWP and was usually one of the most supported candidates, counting deletions and inclusion in other lists. (Author's note: during the interwar period, the elections were accompanied by so-called revolving lists. The voter chose the list closest to him/her in which the number of candidates did not exceed the list of the respective deputies (there could be a nonexhaustive list.) It was also possible to throw the list in the ballot box unchanged, but it was also possible to delete one/more from the list and write the candidate(s) from another list instead. Accordingly, the deleted candidate received less votes, while the registered ones received more votes. The list should not contain more surnames than the number of deputies.) After the election, however, the engineer laid down the deputy's mandate and continued to work on the Board. On 23 April 1931, he also became one of the two deputies of the Mayor, Hugo Celmins (1877-1941), a graduate (1903) of the Department of Agriculture of RPI.

In July 1923, representatives of Latvian cities gathered in the Congress for the first time in the premises of the Riga City Council. In October 1926, the Union of Latvian Cities and Towns was established; J. Jagars was elected the Chairman of its Board. As a representative of the Union he also held a position in the Council of the Mortgage Bank of Latvia and participated in the activities of the State Economic 
Council. Representatives of Latvia participated in the Union of Baltic States' Cities, and Jānis Jagars also attended its meetings in Estonia and Lithuania several times. He participated in various events abroad, he was a representative not only of Riga but also as of the whole of Latvia.

Table 1

Jānis Jagars' business trips abroad (according to press reports)

\begin{tabular}{|l|l|l|}
\hline Year, month & Location & Aim \\
\hline December 1923 & Finland & $\begin{array}{l}\text { Visit of the Latvian Union of } \\
\text { Engineers }\end{array}$ \\
\hline June 1924 & London, England & $\begin{array}{l}\text { Participation in the Use of Force } \\
\text { Conference }\end{array}$ \\
\hline September 1924 & Poland & $\begin{array}{l}\text { Visit of the Latvian Union of } \\
\text { Engineers }\end{array}$ \\
\hline December 1924 & Kaunas, Lithuania & Riga City Delegation \\
\hline July 1925 & Berlin, Germany & $\begin{array}{l}\text { Visit of the Head of the Construction } \\
\text { Board }\end{array}$ \\
\hline September 1926 & Vienna, Austria & $\begin{array}{l}\text { Congress of Urban Development and } \\
\text { Apartments }\end{array}$ \\
\hline February 1927 & Tallinn, Estonia & City Delegation \\
\hline May 1927 & Geneva, Switzerland & World Economic Conference \\
\hline May 1927 & Moscow, USSR & $\begin{array}{l}\text { Preparation of a Trade Agreement } \\
\text { with the USSR }\end{array}$ \\
\hline May 1927 & Seville, Spain & $\begin{array}{l}\text { International Congress of the Union } \\
\text { of Cities }\end{array}$ \\
\hline November 1928 & Kaunas, Lithuania & $\begin{array}{l}\text { Meeting of the Union of Baltic } \\
\text { States' Cities }\end{array}$ \\
\hline April 1929 & $\begin{array}{l}\text { Seville, Barcelona, } \\
\text { Spain }\end{array}$ & $\begin{array}{l}\text { International Congress of the Union } \\
\text { of Cities }\end{array}$ \\
\hline July 1932 & Repubue, Czech & $\begin{array}{l}\text { Return visit; on the way - Lithuania, } \\
\text { Poland, Germany }\end{array}$ \\
\hline August 1932 & Hanko, Finland & $\begin{array}{l}\text { Congress of Representatives of } \\
\text { Finnish Cities }\end{array}$ \\
\hline December 1932 & Tallinn, Narva, Estonia & $\begin{array}{l}\text { Meeting of the Union of Baltic } \\
\text { States' Cities }\end{array}$ \\
\hline March/April 1934 & Nancy, France & Purchase of water supply pipes \\
\hline
\end{tabular}

Reviewing the Latvian press, it must be concluded that the return trip of representatives of Riga to Czechoslovakia in the summer of 1932 was mostly discussed there (the Prague leadership visited Riga in 1930). Mayor of Riga H. Celmiňs and his deputy J. Jagars travelled to Prague by City Council car, visiting several places in Lithuania, Poland and Germany along the way. It was planned that another deputy of H. Celminšs - lawyer 
Valters Sadovskis (1882-1956) - would accompany, but he fell ill. The usefulness of the trip, which lasted about 10 days, was questioned at a time of a city budget deficit. J. Jagars' last business trip took place a month and a half before he was dismissed from the Construction Board. At that time, the employees of the City Board J. Jagars, G. Ulmans and Mārtinš Karlsons (1875-1960) went to France to arrange the purchase of water pipes for the new water pipeline from a well in Zakumuiža District. Engineer J. Jagars participated in the development of Latvian Building Regulations (although they were not adopted), in the discussion of urban planning projects, and participated in the planning of Latvia's energy development.

It is necessary to recall two directions of work of the Construction Board during the time of J. Jagars, which he himself recognized as important. In the second half of the 1920s, city tenement houses were built [23]. It was also inspired by the International Construction Exhibition and the Urban Construction Congress in Vienna, where Riga was represented by engineer J. Jagars and a bibliographer and teacher, Riga City Councillor Teodors Liventāls (1882-1956). The Housing Crisis Combating Commission was established in Riga [24]. First, two-storey row buildings were built on Ropažu and Liepāja Street. This was followed by a five-storey 117-apartment house on Ausekla Street (architect Pāvils Dreijmanis; 1895-1953), and a four-storey house with 118 apartments on Jāna Asara Street (architect Osvalds Tïlmanis; 1900-1980). Two four-storey houses were built on Samarina Street (now - Lomonosova) (architects Ernests Štālbergs (1883-1958), Heinz Pirang (1876-1936)). A total of 594 apartments were built between 1926 and 1930, mostly with one or two rooms, some more spacious, but with the appropriate facilities for that time [25]. The economic crisis stopped further construction of city rental houses for a longer period of time. Engineer J. Jagars headed the Market Construction Commission, which took care of the construction of the Central Market [26]. The final construction project was prepared by joint stock company «Būve». Among its founders in the summer of 1922 were several well-known politicians and economic workers: Voldemārs Bekeris (1881-1941), Jānis Goldmanis (1875-1955), Francis Kemps (1876-1952), Jāzeps Trasuns (1898-1978), former RPI student Ādolfs Blodnieks (1889-1962), graduates of RP / RPI Pauls Ašmanis (1881-1952), Mikelis Bružis (1868-1941) and Markus Gailitis (1882-1942), and brothers Andrejs and Jānis Jagars [27]. At the suggestion of Klāvs Lorencs (1885-1975), the Head of the Department of Sales of the City Board, metal constructions in Vainode from the German airship hangars from World War I were used. The works started in the summer of 1924, they lasted intermittently until the autumn of 1930, as a result of which Riga got the best market buildings of its time in Europe. 
Engineer J. Jagars was a member of the LSDWP Riga City Committee, also an elected Chairman of the Committee. He often spoke at the events of Social Democrats, especially at the 1 May meetings. J. Jagars was in charge ofthe event on 1 May 1934 in Grizinkalns. At that time, the Social Democrat campaign group «Zilā blūze» (Blue Blouse) gave a performance in which they caricatured Germany and Adolf Hitler (1889-1945) in the play «Ugunskrusta dancis» (Fire Cross Dance). It was also watched by an employee of the German Embassy, who demanded condemnation of what he saw. Less than a year later, J. Jagars, the person in charge of the meeting, was sentenced to two weeks in prison in Riga Termincietums [28]. At the beginning of 1934, there were 60 LSDWP members among the employees of the Construction Board, many of them were also among the firefighters of Riga [29]. On 12 April 1931, the engineers were also elected to the LSDWP Central Committee for one year [30]. At the beginning of November 1925, the Cabinet of Ministers headed by Hugo Celminš resigned, and more than a month and a half passed before a new one was approved. On 22 December, a government led by Voldemārs Zāmuels was proposed to the Saeima, which would also have several social democrats, including the position of the Minister of Transport for Jānis Jagars [31]. However, not enough deputies voted for it, the next approved government was headed by Kārlis Ulmanis, it was without the Social Democrats.

Figure 6. J. Jagars' request for the return of the materials seized during the search to his wife (25.06.1934).
Professional and Social Activities of Engineer

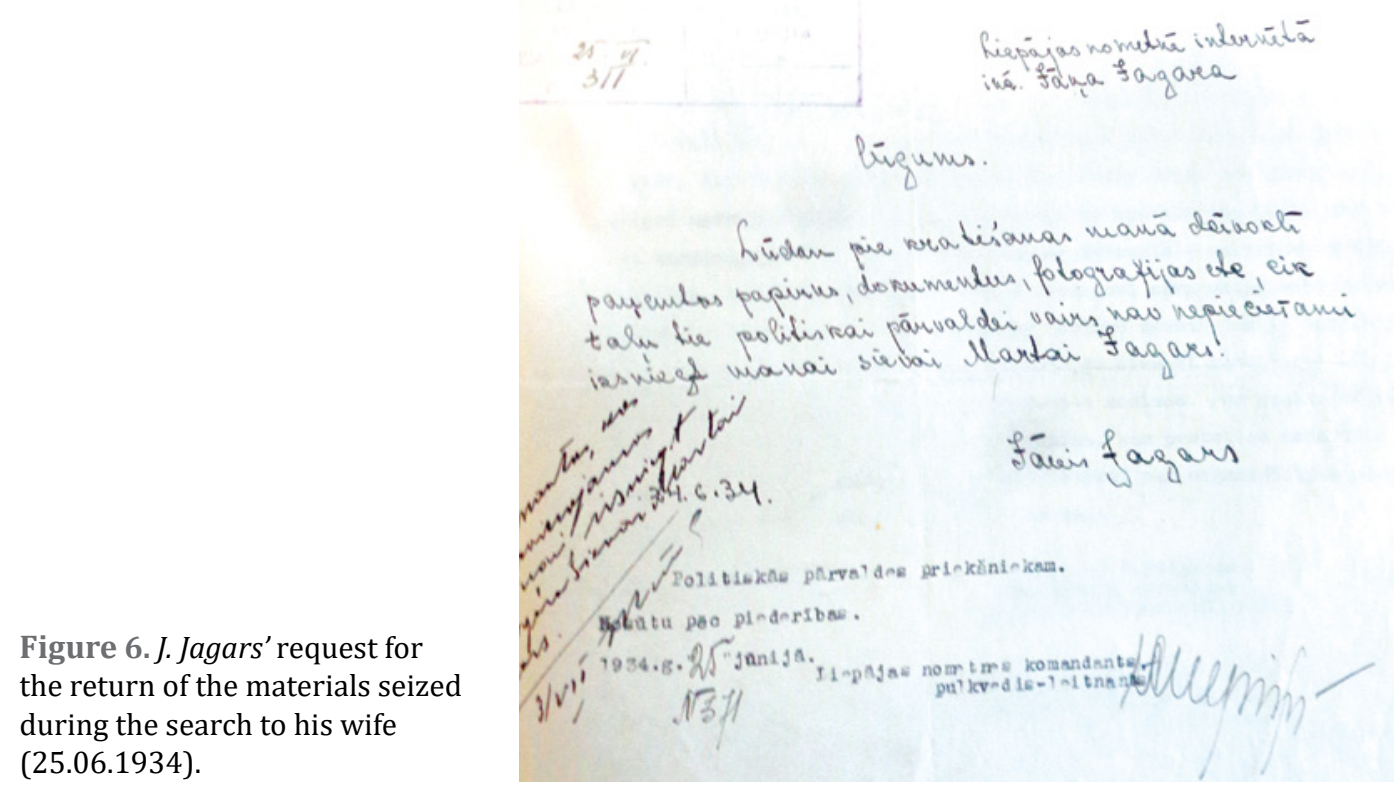


At the time when J. Jagars was working in the Riga City Construction Board, the construction of the Freedom Monument was discussed. At the beginning, the Social Democrats were opposed to the planned creation of a monument, they suggested a more practical object to remind the establishment of the Latvian state, such as a museum, a library building or a new bridge. This opinion was also expressed by J. Jagars who was a member of the Freedom Monument Committee [32]. In 1930, he supported the construction of the monument in the proposed place on the condition that it does not but it should not disturb the city traffic.

The coup d'etat of 15 May 1934 interrupted the activities of the Saeima and elected local governments. The incomplete composition of the Riga City Board (a couple of members arrested at that time - the Social Democrats) met on 18 May. When the proposal for the Mayor $H$. Celmins to congratulate the new government on behalf of the board and wish it much success in its future work was voted for, the Social Democrats J. Jagars and Kārlis Tïfentāls (1891-1963) abstained [33].

On the night of the coup, J. Jagars was in a summer house in Ogre, and he did not spend the next few nights at home. On 16 May, the Head of the Riga District of the Political Administration signed a decision on the search of J. Jagars' apartment, because he "participated and actively worked in several organizations harmful to the interests of the state» [34; p. 1]. The engineer was arrested, and during an interrogation on 23 May he said that he had been a member of the LSDWP since 1919, had also worked for the Latvian Union of Engineers, the Union of Cities' Municipalities, and the International Housing Union, but they were all legal organizations. The respondent did not know anything about the intention of the Social Democrats to prepare for a coup. On 29 May, it was decided to arrest J. Jagars and keep him under arrest in the premises of the Political Administration, the next day he was included in a group of 150 persons to be sent to the Liepajja Concentration Camp. There he shared a room with his father-in-law K. Dékens and his brotherin-law V. Grēvinšs. The rest of the internees lived in larger groups, but the management of the camp has shown a favour towards the elder K. Dékens, allowing him to choose roommates in a small room. In August, a report of the Politburo described a part of the social democrats in the Liepajja Concentration Camp [34; p. 18]. They can be divided into two groups - far-left, the so-called Muscovites, and moderately national. The far-left (Fricis Menders, Ansis Buševics, Klāvs Lorencs, etc.) were standing for the renewal of the organization and cooperation with the Communists. Moderately national (Voldemārs Bastjānis, Roberts Dukurs, Roberts Bīlmanis, Jānis Jagars, Valdis Grēviñš, Rūdolfs Drillis, etc.) considered that the Socialist Democrat Party had lost its foundations. In 
September, J. Jagars was released from the camp on the condition that he refrained from any activity detrimental to the interests of the state [34; p. 21].

Figure 7. J. Jagars promise to refrain from activities harmful to the interests of the state (29.09.1934).

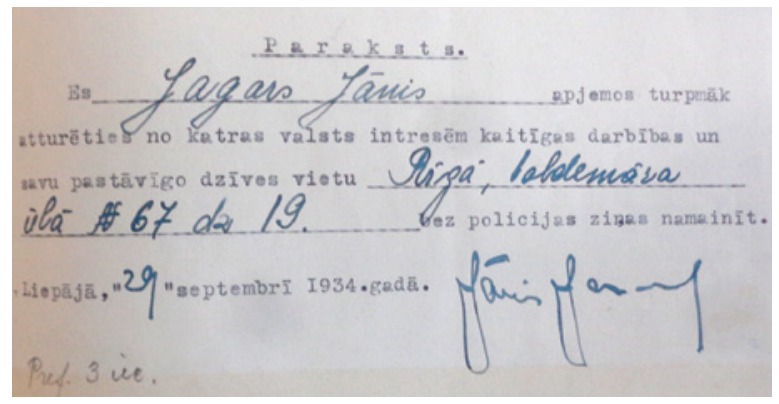

\section{Jānis Jagars - Engineer and Politician. 1934-1940}

After returning from the Liepajja Concentration Camp in the autumn of 1934, J. Jagars did not have an opportunity to find a job in the Riga City Administration or perform duties similar to those of his former positions, although he had already earned a pension of 418 lats per month. J. Jagars together with other social democrats - the already mentioned Klāvs Lorencs as well as Jānis Arvīds Osītis (1910-1994) and a man with surname Bērzs - in 1934 [35] established Engineering Office "Tehnocentrs», which was registered in 1935 in the name of Jānis Jagars' trading company [36]. It was located in Riga, 6 Smilšu Street, from 15 December 1936 - 3 Lielā Jaunavu Street, from 14 August 1939 - 38 Brīvibas Street. The Office offered the services of developing technical and construction projects, all kinds of technical consultations, building construction, central heating, heating installation of water, ventilation, sewerage, water supply, refrigeration and other technical equipment [37]. One of the orders was for the «construction of central heating, ventilation and water supply in the newly built premises of the City Savings Bank and pawnshop» on Baznīcas Street in Liepāja, in 1936 [38]. Liepāja residents chose this project because it had the lowest costs. In the first years, Engineering Office «Tehnocentrs» was quite active. In the summer of 1936, it was also allowed to trade in cars imported from the Soviet Russia [34; p. 29]. One such car was ZIS-14, manufactured at Moscow automobile plant named after Stalin (Завод имени Сталина; ЗИС). The factory produced both cars and trucks and when promoting them, J. Jagars acknowledged that their design and manufacturing was similar to those produced by the most advanced American car companies [39]. K. Lorencs, who had been in economic 
contact with the Soviet authorities since the 1920s as a Board Member and Executive Director of the Cooperative Transit Bank, proposed to import and sell cars [40].

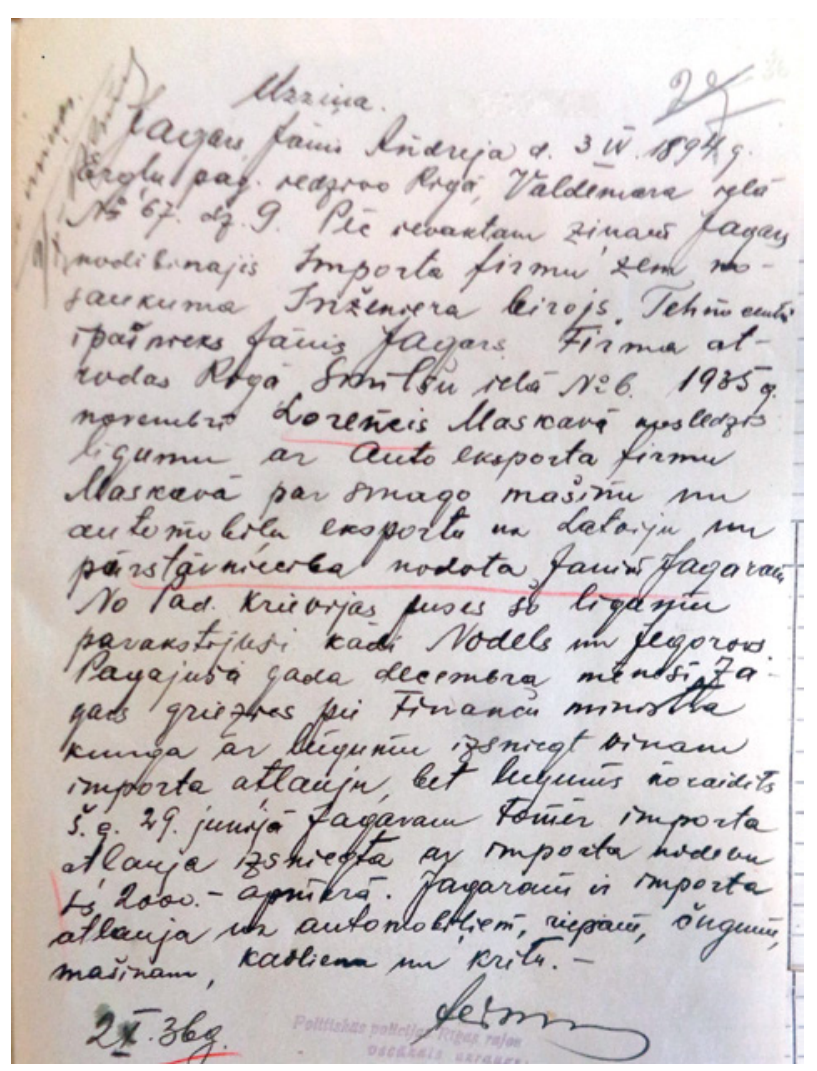

Figure 8. Information prepared by the Politburo on the engineering office «Tehnocentrs» (02.10.1936).

In 1937, the office was included in the list of irregular suppliers and was prohibited to carry out orders from public authorities [41]. In the beginning of 1938, the "mediation office» of Engineering Office «Tehnocentrs» was abolished, but «Tehnocentrs» continued to operate and it must be assumed that it did well. For example, in 1939, in response to the call of the Prime Minister and President Kärlis Ulmanis and the Minister of War, General Jānis Balodis (1881-1965), to donate into the National Defence Fund, «Tehnocentrs» donated 100 lats. In 1938, «Tehnocentrs» patented the automatic economical draft regulation apparatus invented by J. Jagars [42], for which the Patent Office had issued a protection certificate for the invention on 21 September 1935 [43].

The company lost the ban on fulfilling the orders of state institutions on 15 July 1940, during the Soviet rule, when the Head of the Office, 
J. Jagars, was appointed Minister of Transport. The days of the Office were counted because after another 10 days, on 25 July, it was included in the list of nationalized industrial enterprises, and its operation was suspended.

J. Jagars reduced his social activities after the 1934 coup. He joined the Latvian-Estonian Society. This is related to his former work in Kunda and also to the activities of the Union of Baltic States' Cities. His work continued under the leadership of the Society of Engineers, from which J. Jagars was also nominated to the Board of the Union of Latvian Technical Societies in 1936 [44]. Later, in the questionnaire, the engineer indicated that from 1934 to 1940 he was a member of the Latvian Socialist Workers' and Peasants' Party, but was not active [45]. One of the founders of this small party was Klāvs Lorencs, a neighbour of J. Jagars and a partner in the Engineering Office. In 1929, the Society for Cultural Convergence was established with the peoples of the USSR (abbreviation of the Soviet Union), one of the initiators was Valdis Grēviņš, Jānis Jagars also joined. From 1937 he chaired its Audit Commission, he also organized the last general meeting of the Society on 10 July 1940 [46, p. 103]. Mikhail Vetrov (Михаил Ветров; 1909-1980), the first secretary of the USSR's authorized mission to Latvia, was the representative of the respective Soviet organization - All-Union Society for Cultural Relations [49, p. 92]. It has to be noted that several ministers of the People's Government had been the Society members.

As the political situation changed, the composition of the new government was announced in June 1940, and Jānis Jagars held the position of Minister of Transport [47]. In the evening of 20 June, the newly proclaimed ministers had a meeting with President Kārlis Ulmanis, J. Jagars was not present. The next day he attended the first meeting of the People's Government. Twenty-five years later, journalist Pēteris Blaus (1900-1971), the Minister for Public Affairs of the A. Kirhenšteins Government, co-organized a radio recording with J. Jagars and Vikentijs Latkovskis (1899-1983), a member of the A. Kirhenšteins' Minister of the Interior [48]. J. Jagars mentioned his previous disagreements with K. Ulmanis. The Latvian Railway, the Highway and Land Road Service, as well as the Post Office and the Telegraph operated under the supervision of the Ministry of Transport. In all these institutions, senior staff were gradually replaced. After Latvia was included in the Union of Soviet Socialist Republics (USSR), the Council of People's Commissars replaced the Cabinet of Ministers in accordance with the existing procedures. From August 1940, Jānis Jagars was the People's Commissar of the Utilities of the Latvian SSR and formally retained this position during World War II. 


\section{Jānis Jagars - Engineer and Politician. 1941-1950}

At the end of June 1941, J. Jagars managed to leave for Soviet Russia with his family. The engineer became a representative of the Central Committee of the Latvian Communist (Bolshevik) Party and the Council of People's Commissars of the Latvian Soviet Socialist Republic (LSSR) for the issues of Latvian refugees in Bashkiria and Chkalov region. In the spring of 1944, he was included in the operative group of the Riga City Executive Committee to be in charge of electrification, gas management, water supply and sewerage. J. Jagars returned to Riga in the middle of October, later he lived at $67 \mathrm{~K}$. Valdemāra Street, apartment No. 16 (his previous apartment was occupied, part of the belongings had been preserved by $K$. Lorencs during the German occupation). Yet, the engineer worked in the project expertise group of the working group of the Department of Architectural Affairs of the Council of People's Commissars of the LSSR, then - until the autumn of 1946 - he headed the Department of Settlement Planning, Residential and Public Building Design.

From 9 November 1944, Jānis Jagars was a lecturer of the Faculty of Engineering of the SUL [12; p. 13]. The engineer was hired as an Assistant Professor with a candidate's degree by order of the Rector, although he submitted only a copy of the temporary certificate of the graduate of the BTU. In July 1947, the title of Assistant Professor of the Chair of Building Structures (headed by the later Rector of RPI (1961-1963) Aleksandrs Mālmeisters (1911-1996)) was also approved for J. Jagars by the Attestation Commission of the USSR Ministry of Higher Education [12; p. 6]. According to the descriptions, he carried out the duties of a lecturer successfully due to his extensive previous experience, however he did not participate in the social life of the university because of his busy schedule. On 3 January 1950, the Assistant Professor was released, stating that he had worked outside the university without the permission of the Ministry of Higher Education [12; p. 19]. In the documents previously submitted to the University, J. Jagars mentioned his employment both in the Department of Architectural Affairs and in the Academy of Sciences of the Latvian Soviet Socialist Republic (LSSR).

From April 1946, for the next five years, J. Jagars worked at the Institute of Architecture and Construction of the Academy of Sciences of the Latvian SSR, founded in February 1946, and was the Deputy of Director of Research Ernests Štālbergs. Here, too, the knowledge accumulated during his employment in the Construction Board could be used. J. Jagars, for example, prepared a report on the reconstruction of Latvian cities, he had been writing about similar issues in magazine «Pašvaldību Dzīve» (Municipal Life) since the 1920s, because as a 
member of the board of the Union of Latvian Cities he had got acquainted with the economy of different cities. The engineer headed a working group on the topic «Industriālās un paātrinātās celtniecības metožu ieviešana Latvijas PSR» (Introduction of Industrial and Accelerated Construction Methods in the Latvian SSR) [49]. The Deputy Director's research paper at the 2nd Congress of Architects of the Latvian SSR was then criticized for insufficient principledness in evaluating the Institute's performance [50]. Seven years later, at the 4th Congress, J. Jagars was elected to the Board of the Union of Architects of the Latvian SSR and was re-elected at the next three congresses of the Union. After leaving the Institute of Architecture and Construction, J. Jagars worked at the Institute of Agricultural Construction Design, later - headed a department at the Baltic Branch of the Design Institute of All-Union Meat and Dairy Industry, and finally - moved to the Institute of Latvian Urban Construction Design.

Figure 9. J. Jagars (standing) working with students of the Faculty of Engineering of SUL (second half of the 1940s).

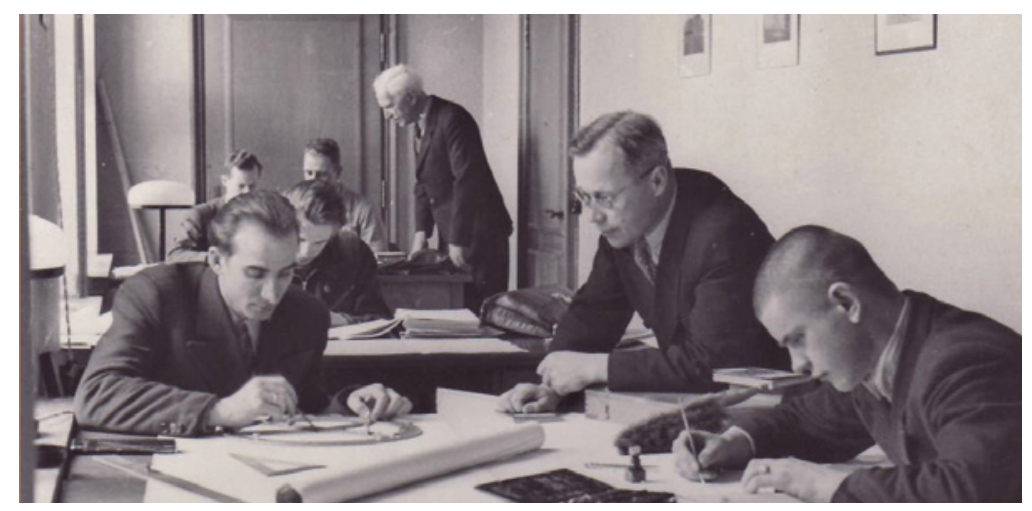

\section{Conclusions}

The present research evaluated the life and work of engineer J. Jagars from various aspects taking into consideration that it took place in different political systems: first, in tsarist Russia, then in the Republic of Latvia, and at the end of his life - in Soviet Latvia. He took active part in political activities, was a «moderate social democrat and a man of a calm nature» [51], and was actively involved in the development and consolidation of engineering thought in Latvia as well as in inventors' movement.

Since his studies at RPI, J. Jagars has been closely connected with other RPI students and graduates. His wife Marta also wanted to study at this university in 1917, but in the conditions of World War I it was not possible to leave Riga for Moscow, where the evacuated university 
operated [52]. The engineer also had a daughter, SUL graduate Rūta. The brother's daughter, architect and a social worker in exile Laima Kalnina (1922-2019), began her studies at the Faculty of Architecture of the University of Latvia in 1940 and lived in the United States after World War II. There she acted as Secretary General of the World Federation of Free Latvians. The grandson of Jānis Jagars' sister Marija is a diplomat Ints Siliňs, who was the first US Ambassador to Latvia after the restoration of Latvia's independence from 1992 to 1995.

In the 1920s, when J. Jagars held the position of an engineer, the development of architecture was promoted - the Riga Central Market was built, as well as several block houses, which also serve in the 21st century. After World War II, he was no longer involved in politics [53]. The life of engineer J. Jagars ended at the age of 76 on 2 February 1970. He is buried next to his wife in Riga, in Rainis cemetery. Both children also rest there.

\section{REFERENCES}

[1] Jāṇa Jagara autobiogrāfija. Latvijas Arhitektūras muzejs, AM/J3-5, 1., 6., 8., 10., 11. lp.

[2] Ērg̣̣u draudzē laulāto saraksts Latvijas Nacionālā arhīva Latvijas Valsts vēstures arhīvs (turpmāk - LNA LVVA), 235. f., 7. apr., 211. 1., 8. lp.

[3] RPI studenta J. Jagara personāllieta. LNA LVVA, 7175. f., 1.apr., 1814. l., 9.-10. lp.

[4] Miris inž. A. Jagars. Laiks, 1969. gada 3. septembris, Nr. 70, 5. lpp.

[5] Mājas grāmata ēkai Rīgā, Valdemāra ielā 67. LNA LVVA 2942. f., 1. apr., 14400. l., 155. lp.

[6] Daija, G. Latvijas Universitātes studentu biedrības. Rīga: Latvijas Universitāte, 1994, 39., 65. lpp

[7] RPI studentu saraksti. LNA LVVA 7175. f., 1. apr., 1909. 1., 212. lp.

[8] Prēdele, J. RPI vēsturiskajā 1917. gadā. Jaunais Inženieris, 1967. gada 12 oktobris, Nr. 18, 2. lpp.

[9] Vietējās ziṇas. Jaunākās Zingas, 1918. gada 26. novembris, Nr. 10, 5. lpp.

[10] Vietējās ziṇas. Baltijas Vēstnesis, 1918. gada 26. novembris, Nr.11, 2. lpp.

[11] Brunners, A. Oldermaña 18. novembra atminnas. Universitas, 1968. gada 1. oktobris, Nr. 22, 6. lpp.

[12] Jāṇa Jagara personāllieta. LU arhīvs, 2172. f., 7. apr., 1064. l., 6., 13., 19. lp.

[13] Ministru kabineta sēde 28. septembrī. Valdības Vēstnesis, 1925. gada 29. septembris, Nr. 217, 2. lpp.

[14] Ministru kabineta sēde 2. oktobrī. Latvijas Kareivis, 1925. gada 4. oktobrī, Nr. 224, 2. lpp.

[15] Brūvelis, E. Latvijas aviācijas vēsture. Rīga: Jumava, 2003, 54. lpp. 
[16] Ar Triju zvaigžņu ordeni apbalvoto saraksts. Valdības Vēstnesis, 1930. gada 17. novembris, Nr. 261, 2. lpp.

[17] Grāvis, P. Zemkopības ministrijas noorganizēšana. Latvijas agrārā reforma. Rīga: Zemkopības ministrijas izdevums, 1930, 238. lpp.

[18] Latvija. Tautas padome. Strādnieku Avīze, 1919. gada 17. jūlijs, Nr. 63, 1.-2. lpp.

[19] Iecelšanas. Valdības Vēstnesis, 1922. gada 2. augusts, Nr. 169, 1. lpp.

[20] Eihe, K. Vai tehniskā departamenta dibināšana pie zemkopības ministrijas ir vajadzīga? Brīvā Zeme, 1922. gada 28. novembris, Nr. 268, 2. lpp.

[21] Likums par tehniski-arodnieciskā grāda un tiesību piešķ̧iršanu un lietošanu (Kongresu biroja priekšlikums). Latvijas Inženieru un Tehniķu Kongresa Biroja Žurnāls, 1924. gada janvāris, Nr. 3.-4, 118.-119. lpp.

[22] Kuzis, J. Rīgas pilsētas pašvaldības juridiskā uzbūve. Rīga kā Latvijas galvas pilsēta. Rīga: Rīgas pilsētas valde, 1932, 214. lpp.

[23] Jagars, J. Komunālo dzīvokḷu celtniecība, Rīga kā Latvijas galvas pilsēta. Rīga: Rīgas pilsētas valde, 1932, 509.-522. lpp.

[24] Vīnes starptautiskā pilsētu izbūves un dzīvokḷu kongresa atskaṇas. Sociāldemokrāts, 1926. gada 2. novembris, Nr. 247, 2.-3. lpp.

[25] Blokmāju iemītnieki pateicas b. J. Jagaram un socialdemokrātu frakcijai. Sociāldemokrāts, 1931. gada 20. februāris, Nr. 41, 5. lpp.

[26] Jagars, J. Centrāltirgus būve. Rīga kā Latvijas galvas pilsēta. Rīga: Rīgas pilsētas valde, 1932, 387.-394. lpp.

[27] Akciju sabiedrības «Būve» statūti. Ekonomists, 1923. gada 1. februāris, Nr. 3, 85. lpp.

[28] Sodīts inž. Jagars. Brīvā Zeme, 1935. gada 27. marts Nr. 72, 4. lpp.

[29] LSDSP biedru saraksts, kas glabājās pie J. Jagara. LNA LVVA 3235. f., 2. apr., 5442. l., 27. lp.

[30] Mūsu partijas 16. kongresa otrā diena. Sociāldemokrāts, 1931. gada 14. aprīlis, Nr. 81, 2. lpp.

[31] Saeima. Valdības Vēstnesis, 1925. gada 23. decembris, Nr. 288, 1. lpp.

[32] Nedzīvais piemineklis dzimst. Sociāldemokrāts, 1928. gada 13. janvāris, Nr. 10, 2. lpp.

[33] Rīgas pilsētas valde apsveic valdību. Centra Balss, 1934. gada 19. maijs, Nr. 20, 4. lpp.

[34] Lēmums par kratīšanu J. Jagara dzīvesvietā un dienesta atzīmes, J. Jagara paraksts par atturēšanos no kaitīgas darbības, uzzina. LNA LVVA 3235. f., 2. apr., 5442. 1., 1., 18., 21., 29. lp.

[35] Inž. Jānis Jagars. Dzelzceḷu Vēstnesis, 1940. gada 22. jūnijā, Nr. 23, 6. lpp.

[36] Tiesu sludinājumi. Valdības Vēstnesis, 1935. gada 6. jūlijs, Nr. 149, 5. lpp.

[37] Inženieru birojs «Tehnocentrs». Rìts, 1935. gada 6. novembris, Nr. 308, 4. lpp.

[38] Pilsētas valdes lēmumi. Kurzemes Vārds, 1936. gada 5. jūnijā, Nr. 124, 3. lpp. 
[39] Kāds transporta auto visvairāk piemērots Latvijas ceḷa apstākḷiem un transporta vajadzībām? Ilustrētā Tehnika. Motors un Sports, 1937. gada janvāris, Nr. 1, 10.-11.lpp.

[40] Strenga, A. Latvijas un Padomju Krievijas miera ligums 1920. gada 11. augustā. Rīga: Mansards, 2020, 350. lpp.

[41] Valdības iestāžu paziṇojumi. Valdības Vēstnesis, 1937. gada 11. jūnijs, Nr. 128, 3. lpp.

[42] Patentu valde. Valdības Vēstnesis, 1938. gada 5. jūlijs, Nr. 147, 1. lpp.

[43] Patentu valde. Valdības Vēstnesis, 1935. gada 2. decembris, Nr. 274, 3. lpp.

[44] No biedrību dzīves. Mērniecības un Kultūrtehnikas Vēstnesis, 1936. gada janvāris-februāris, Nr. 1-2, 26.-28. lpp.

[45] J. Jagara kadru anketa, Latvijas Nacionālais arhīva Latvijas Valsts arhīvs, 15500. f., 2. apr., 6797. 1., 3. lpp.

[46] Daukšts, B. Kulturālās tuvināšanās biedrība ar SPRS tautām (19291940). Rīga: LU Akadēmiskais apgāds, 2012, 92., 103. lpp.

[47] Paziṇojums. Valdības Vēstnesis, 1940. gada 21. jūnijs, Nr. 138, 1. lpp.

[48] Atminnas par 1940. gada notikumiem (P. Blaus, J. Jagars, V. Latkovskis) [tiešsaiste]. http://www.diva.lv/audio/atminas-par-1940-gada-notikumiemp-blaus-j-jagars-v-latkovskis/atminas-par-1940-gada-notikumiem-p-blaus-jjagars-v-latkovskis [skatīts: 31.12.2020].

[49] Arhitektūras un celtniecības institūta darba plāns 1946.-1950. gadam. LNA LVVA, 2359. f., 1. apr., 2. 1., 3. lp.

[50] Birzīte, L. Latvijas padomju arhitektūras neatliekamie uzdevumi. Cīna, 1948. gada 2. jūnijs, Nr. 129, 2. lpp.

[51] Bērziṇš, A. Pēdējais gads. Lauku Avīze, 1992. gada 16. oktobris, Nr. 42, 11. lpp.

[52] Zigmunde, A. Sievietes Rīgas Politehniskajā institūtā 20. gadsimta sākumā. Inženierzinātñu un augstskolu vēsture 2017/1, 113. lpp.

[53] Miris Jānis Jagars. Brīvība, 1970. gada 1. marts, Nr. 3, 5. lpp.

\section{SOURCES OF ILLUSTRATIONS}

Figure 1. J. Jagara pase. LVVA 2996. f., 9. apr., 275. l.

Figure 2. Gundegas Saulītes privātarhīvs.

Figure 3. RPI studenta J. Jagara personāllieta. LNA LVVA 7175. f., 1. apr., 1814. I., 5. lp.

Figure 4. LSDSP biedru saraksts, kas glabājās pie J. Jagara. LNA LVVA 3235. f., 2. apr., 5442. 1., 32. lp.

Figure 5. Latvijas arhitektūras muzejs, AM/J3-2.

Figure 6. LSDSP biedru saraksts, kas glabājās pie J. Jagara. LNA LVVA 3235. f., 2. apr., 5442. l., 16. lp.

Figure 7. LSDSP biedru saraksts, kas glabājās pie J. Jagara. LNA LVVA 3235. f., 2. apr., 5442. l., 21. lp. 
Figure 8. LSDSP biedru saraksts, kas glabājās pie J. Jagara. LNA LVVA 3235. f., 2. apr., 5442. l., 27. lp.

Figure 9. Latvijas Ceḷu muzeja krājums.

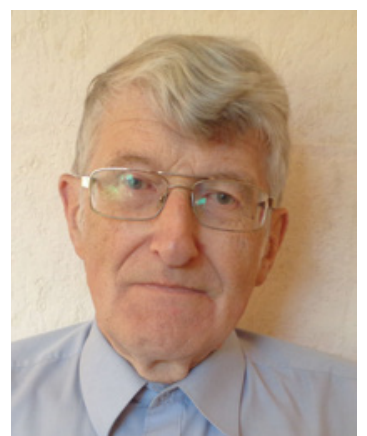

INDULIS ZVIRGZDIN̦Š, Mg. hist. (1996, University of Latvia), was a Senior Researcher of the Madona Museum of Local History and Art, member of the Latvian Association of History of Science. His main academic interests include the history of Madona and Madona District. He is the author of many publications.

Address: Skolas Street 12, Madona, LV-4801, Latvia E-mail: zviindulis6@inbox.lv

\section{Indulis Zvirgzdiņš}

\section{Inženiera Jāṇa Jagara (1894-1970) profesionālā un sabiedriskā darbība}

Pētījums atklāj inženiera Jāṇa Jagara (1894-1970) dzimtas un viṇa darbības daudzpusību 20. gadsimtā. Viṇš studējis Rīgas Politehniskajā institūtā (RPI), Pirmā pasaules kara laikā uzturējies Krievijā. Pēc atgriešanās Latvijā 1919. gada sākumā absolvējis BTA, kas bija nodibināta uz RPI bāzes. J. Jagars darbojās Latvijas Sociāldemokrātiskajā strādnieku partijā (LSDSP), ar tās atbalstu kluva par Rīgas pilsētas Būvvaldes vadītāju, pēc Kārḷa Ulmaṇa (1877-1942) organizētā valsts apvērsuma tika apcietināts, pēc tam - atbrīvots un vadījis inženieru biroju, 1940. gada jūnijā iekḷauts Augusta Kirhenšteina (1872-1963) vadītajā valdībā, ieṇemot satiksmes ministra amatu. Otrā pasaules kara laikā evakuējies uz Padomju Krieviju. Pēc kara J. Jagars bija Latvijas Valsts universitātes (LVU) docents, strādāja dažādos celtniecības projektēšanas institūtos.

Atslēgas vārdi: Jānis Jagars, Rīgas Politehniskais institūts, Baltijas Tehniskā augstskola, Rīgas pilsētas Būvvalde, Latvijas Valsts universitāte 